University of Nebraska - Lincoln

DigitalCommons@University of Nebraska - Lincoln

\title{
The Cercospora nicotianae gene encoding dual 0- methyltransferase and FAD-dependent monooxygenase domains mediates cercosporin toxin biosynthesis
}

\author{
Katherine L. Dekkers \\ Bang-Jau You \\ Vivek S. Gowda \\ Hui-Ling Liao \\ Miin-Huey Lee \\ See next page for additional authors
}

Follow this and additional works at: https://digitalcommons.unl.edu/usdaarsfacpub

Part of the Agricultural Science Commons

Dekkers, Katherine L.; You, Bang-Jau; Gowda, Vivek S.; Liao, Hui-Ling; Lee, Miin-Huey; Bau, Huey-Jiunn; Ueng, Peter P.; and Chung, Kuang-Ren, "The Cercospora nicotianae gene encoding dual Omethyltransferase and FAD-dependent monooxygenase domains mediates cercosporin toxin biosynthesis" (2007). Publications from USDA-ARS / UNL Faculty. 382.

https://digitalcommons.unl.edu/usdaarsfacpub/382

This Article is brought to you for free and open access by the U.S. Department of Agriculture: Agricultural Research Service, Lincoln, Nebraska at DigitalCommons@University of Nebraska - Lincoln. It has been accepted for inclusion in Publications from USDA-ARS / UNL Faculty by an authorized administrator of DigitalCommons@University of Nebraska - Lincoln. 


\section{Authors}

Katherine L. Dekkers, Bang-Jau You, Vivek S. Gowda, Hui-Ling Liao, Miin-Huey Lee, Huey-Jiunn Bau, Peter P. Ueng, and Kuang-Ren Chung 


\title{
The Cercospora nicotianae gene encoding dual $O$-methyltransferase and FAD-dependent monooxygenase domains mediates cercosporin toxin biosynthesis
}

\author{
Katherine L. Dekkers ${ }^{\text {a }}$, Bang-Jau You ${ }^{\text {a, }}$, Vivek S. Gowda ${ }^{\text {a }}$, Hui-Ling Liao ${ }^{\text {a,b }}$, \\ Miin-Huey Lee ${ }^{\mathrm{c}}$, Huey-Jiunn Bau ${ }^{\mathrm{d}}$, Peter P. Ueng ${ }^{\mathrm{e}}$, Kuang-Ren Chung a,b,*

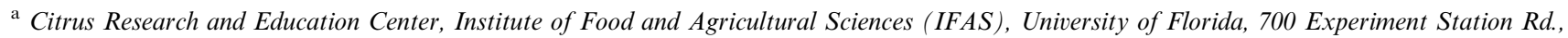 \\ Lake Alfred, FL 33850, USA \\ ${ }^{\mathrm{b}}$ Department of Plant Pathology, IFAS, University of Florida, Gainesville, FL 32611, USA \\ ${ }^{\mathrm{c}}$ Department of Plant Pathology, National Chung-Hsing University, Taichung, 402 Taiwan, ROC \\ d Department of Biotechnology, Transworld Institute Technology, Douliu, 640 Taiwan, ROC \\ ${ }^{\mathrm{e}}$ Molecular Plant Pathology Lab., United States Department of Agriculture-Agricultural Research Service, BARC-West, 10300 Baltimore Ave., \\ Beltsville, MD 20705, USA
}

Received 17 July 2006; accepted 30 August 2006

Available online 30 October 2006

\begin{abstract}
Cercosporin, a photo-activated, non-host-selective phytotoxin produced by many species of the plant pathogenic fungus Cercospora, causes peroxidation of plant cell membranes by generating reactive oxygen species and is an important virulence determinant. Here we report a new gene, $C T B 3$ that is involved in cercosporin biosynthesis in Cercospora nicotianae. CTB3 is adjacent to a previously identified $C T B 1$ encoding a polyketide synthase which is also required for cercosporin production. CTB3 contains a putative $O$-methyltransferase domain in the N-terminus and a putative flavin adenine dinucleotide (FAD)-dependent monooxygenase domain in the C-terminus. The N-terminal amino acid sequence also is similar to that of the transcription enhancer AFLS (formerly AFLJ) involved in aflatoxin biosynthesis. Expression of $C T B 3$ was differentially regulated by light, medium, nitrogen and carbon sources and pH. Disruption of the Nor C-terminus of CTB3 yielded mutants that failed to accumulate the CTB3 transcript and cercosporin. The $\Delta$ ctb3 disruptants produced a yellow pigment that is not toxic to tobacco suspension cells. Production of cercosporin in a $\Delta$ ctb3 null mutant was fully restored when transformed with a functional $C T B 3$ clone or when paired with a $\Delta$ ctb1-null mutant (defective in polyketide synthase) by cross feeding of the biosynthetic intermediates. Pathogenicity assays using detached tobacco leaves revealed that the $\Delta$ ctb3 disruptants drastically reduced lesion formation.
\end{abstract}

(C) 2006 Elsevier Inc. All rights reserved.

Keywords: Clustering; Gene replacement; Perylenequinone; Photosensitizer

\section{Introduction}

Cercosporin is a non-host-selective, photo-activated toxin produced by many phytopathogenic Cercospora species. Cercospora species cause leaf spot and blight diseases on a wide range of plant species, including many economically important crops such as corn, soybean, sugar beet, coffee,

\footnotetext{
${ }^{*}$ Corresponding author. Fax: +1 8639564631.

E-mail address: krchung@ufl.edu (K.-R. Chung).
}

peanut, rice, banana, tobacco as well as ornamental, vegetable and weed species (Daub and Ehrenshaft, 2000). Production of cercosporin has been proven to be essential for full virulence of Cercospora nicotianae in the invasion of hosts and for lesion formation on tobacco (Choquer et al., 2005).

Cercosporin belongs to a class of photosensitizing compounds that are activated upon exposure to light and thus is not toxic to cells in the dark. The perylenequinone chromophore of cercosporin absorbs light energy to attain an 
electronically-activated triplet state and produces active oxygen species such as the hydroxyl $\operatorname{radical}(\mathrm{OH})$, superoxide $\left(\mathrm{O}_{2}^{-}\right)$, hydrogen peroxide $\left(\mathrm{H}_{2} \mathrm{O}_{2}\right)$ or singlet oxygen $\left({ }^{1} \mathrm{O}_{2}\right)$ upon reaction with oxygen molecules (Foote, 1976; Spikes, 1989). These reactive oxygen species cause damage to various cellular components including lipids, proteins and nucleic acids (Daub and Ehrenshaft, 2000). Cercosporin has been shown to produce both ${ }^{1} \mathrm{O}_{2}$ and $\mathrm{O}_{2}^{--}$, causing peroxidation of cell membrane lipids and consequently electrolyte leakage in plants (Daub, 1982a; Daub and Briggs, 1983; Daub and Hangarter, 1983). Due to the production of reactive oxygen species, cercosporin has universal toxicity not only to host plants, but also to fungi, bacteria and mice (Daub, 1982b; Ito, 1981; Yamazaki et al., 1975).

The toxicity of cercosporin to cells and the cellular mechanisms operating in the fungus for cercosporin selfprotection have been intensively investigated (reviewed by Daub et al., 2005). By contrast, the biochemical pathway leading to the cercosporin production is largely unknown. It has been known for a long time that light is absolutely required for cercosporin production (Yamazaki et al., 1975). Studies on physiological factors regulating cercosporin production, however, revealed that accumulation of cercosporin in culture also was markedly influenced by temperature, medium composition, developmental stages and other environmental conditions and varied among isolates (Jenns et al., 1989). Studies using pharmacological inhibitors implicated the involvement of calcium and calmodulin signaling in cercosporin production (Chung, 2003). Studies using a precursor feeding also pointed out that cercosporin is synthesized via a polyketide pathway starting at condensation of acetate and malonate units (Okubo et al., 1975). Recently, several genes in Cercospora spp. have been cloned and demonstrated to be involved in cercosporin accumulation in culture (Callahan et al., 1999; Chung et al., 1999, 2003a; Shim and Dunkle, 2003). However, none of these genes are directly involved in the biosynthetic steps of cercosporin. To identify genes directly involved in cercosporin biosynthesis, C. nicotianae mutants completely deficient in cercosporin production were generated using the restriction enzyme-mediated integration (REMI) mutagenesis (Chung et al., 2003b). A CTBI (Cercosporin Toxin Biosynthesis) gene encoding a fungal polyketide synthase was subsequently identified from one of the REMI mutants and shown by gene disruption to be required for cercosporin biosynthesis and for high levels of virulence on tobacco (Choquer et al., 2005).

Gene clusters involved in the biosynthesis of secondary metabolites have been reported in many filamentous fungi (Keller and Hohn, 1997; Walton, 2000). Some examples include the biosynthetic genes for sterigmatocystin and aflatoxin in Aspergillus species, fumonisin and trichothecene in Fusarium (Gibberella) species, sirodesmin in Leptosphaeria maculans, compactin in Penicillium citrinum, gibberellin in Gibberella fujikuroi, alkaloids in Claviceps purpurea and Neotyphodium uncinatum, AK toxin in Alternaria alternata and $\mathrm{HC}$ toxin in Cochliobolus carbonum
(Abe et al., 2002; Ahn and Walton, 1996; Brown et al., 1996, 1999; Gardiner et al., 2004; Hohn et al., 1993; Proctor et al., 2003; Seo et al., 2001; Spiering et al., 2005; Tanaka and Tsuge, 2000; Tudzynski and Hölter, 1998; $\mathrm{Yu}$ et al., 2004). Thus, we hypothesize that genes involved in cercosporin biosynthesis also are clustered in Cercospora spp. In this study we describe cloning and characterization of a second gene, named $C T B 3$, which is immediately adjacent to the $C T B 1$ gene, to gain further insight into the molecular basis of cercosporin biosynthesis and regulation. The CTB3 contains two putative domains: an $O$-methyltransferase domain in the $\mathrm{N}$-terminus and a flavin adenine dinucleotide (FAD)-dependent monooxygenase domain in the $\mathrm{C}$-terminus. Functional analysis indicated that $C T B 3$ also is required for cercosporin production. The results imply that many, if not all, genes involved in cercosporin biosynthesis and regulation are likely clustered in $C$. nicotianae.

\section{Materials and methods}

\subsection{Fungal strains, media and cultural conditions}

Cercospora nicotianae wild-type strain $\mathrm{CnA}$ (ATCC18366) and other mutant strains were maintained on complete medium $(\mathrm{CM})$ agar plate at $28^{\circ} \mathrm{C}$ (Jenns et al., 1989). For DNA and RNA purification, fungal strains were grown on $\mathrm{CM}$ or potato dextrose agar (PDA) (Difco, Detroit, MI) with a layer of cellophane. Fungal isolates were grown in $50 \mathrm{ml}$ of potato dextrose broth supplemented with $100 \mathrm{mM} \mathrm{Ca}\left(\mathrm{NO}_{3}\right) \cdot 4 \mathrm{H}_{2} \mathrm{O}$ in a rotary shaker for 5 days in the dark for protoplast preparation. Screening of cercosporin-deficient mutants was conducted on PDA plates as previously described (Chung et al., 2003b). Assays for photosensitizer sensitivity were conducted on CM medium under continuous light as described by Jenns and Daub (1995). Pure cercosporin and other photosensitizing dyes (eosine $\mathrm{Y}$, methylene blue or toluidine blue) were purchased from Sigma-Aldrich (St. Louis, MO), and dissolved in acetone to make a $10 \mathrm{mM}$ stock solution. The $\mathrm{pH}$ of PDA was adjusted with $0.1 \mathrm{M}$ citric acid-0.2 M dibasic sodium phosphate buffer (Ruzin, 1999).

\subsection{Toxin purification and quantification}

Cercosporin and other pigments produced by the wild type and the $\Delta$ ctb3 disruptants were extracted with $5 \mathrm{~N}$ $\mathrm{KOH}$ from agar plugs with mycelia as described previously (Choquer et al., 2005; Chung, 2003). Cercosporin in the $\mathrm{KOH}$ extracts was quantified by measuring absorbance at $480 \mathrm{~nm}$ using a model Genesys 5 spectrophotometer (Spectronic Instruments, Rochester, NY). For TLC and HPLC analyses, cercosporin and putative intermediates were purified from agar plugs with mycelia with ethyl acetate. The organic solvent was evaporated with a Model R110 of Rotavapor (Brinkmann, Büchi, Switzerland) and the 
compounds were dissolved in acetone. Thin-layer chromatography (TLC) on plates coated with a 60 F254 fluorescent silica gel $(5 \times 20 \mathrm{~cm}$, Selecto Scientific Inc., Suwanee, GA) and a solvent system containing ethyl acetate:hexane:methanol: $\mathrm{H}_{2} \mathrm{O}(6: 4: 1.5: 1, \mathrm{v} / \mathrm{v})$ was as described by Fore et al. (1988). HPLC was performed in a series 1050 Hewlett Packard autosampler equipped with a Nucleosil 120-5C18 reversed phase column $(5 \mu \mathrm{m}, 250 \times 4 \mathrm{~mm})$ (Richard Scientific, Novato, CA) and using 5-95\% acetonitrile gradient as a mobile phase. Cercosporin and related compounds were detected using a Model 490E detector (Waters-Millipore) at $480 \mathrm{~nm}$.

\subsection{Cloning and sequencing of the full-length CTB3 gene}

The full-length $C T B 3$ sequence of $C$. nicotianae was identified from a previously isolated genomic clone, pPKS-8, containing the $5^{\prime}$-end of the $C T B 1$ gene encoding a fungal polyketide synthase and its upstream sequence (Choquer et al., 2005). DNA sequence analysis was performed in both directions at the Integrated Biotechnology Laboratory, University of Georgia (Athens).

\subsection{Gene disruption and genetic complementation}

All DNA clones were built on a pGEM-T easy vector (Promega, Madison, WI). To disrupt the N-terminus of CTB3, two-step PCR was used to create a CTB3 disruption vector pVG2 (Fig. 1A). A 2.9-kb CTB3 fragment was amplified with the primers P22 (5'-ggcagcaccagtatccacga-3') and OMT-1 (5'-ctcttttgacatccegcacc-3') by an Expand High Fidelity PCR system (Roche Applied Science, Indianapolis, IN). Primers OMT-1 paired with OMT-2 (5'-gagcgg cttgagtttgagcatcgc- $\left.3^{\prime}\right)$, and OMT-3 (5'-gcgcagcactgaaa cctgggg- $3^{\prime}$ ) paired with P22 were used to amplify 1.0 and $0.8 \mathrm{~kb}$ fragments, respectively, and ligated to a $1.6 \mathrm{~kb}$ Bam HI fragment containing hygromycin phosphotransferase B gene $(H Y G)$ cassette from pUCATPH (Lu et al., 1994). A 3.4-kb fragment containing $H Y G$ flanked by CTB3 sequence was cloned to produce $\mathrm{pVG}$. DNA fragments overlapping within the $H Y G$ region were amplified with primers P22 and hyg3 (5'-ggatgcctccgctcgaagta-3'), and primers OMT-1 and hyg4 (5'-cgttgcaagaactgcctgaa$\left.3^{\prime}\right)$. PCR fragments were directly transformed into the $C$. nicotianae wild-type strain for gene replacement.

To disrupt the $\mathrm{C}$-terminus of CTB3, a $4.2-\mathrm{kb}$ CTB3 fragment was amplified with primers CTB3H (5'-aggagcg gattcgatgccetcatg-3') and $\mathrm{P} 40$ (5'-cagctacgatgagtccgagg c-3') and cloned to yield pCTB3G. A 1.0-kb ClaI and AgeI fragment of the $C T B 3$ gene was excised from plasmid pCTB3G and replaced with the end-filled EcoRI/HindIII phosphinothricin acetyltransferase gene $(B A R)$ gene under the Cochliobolus heterostrophus promoter 1 (P1) from pBP1T (Straubinger et al., 1992) to result in pCTB3/Bar6 (Fig. 2A). Split BAR maker fragments obtained by PCR with the primers $\mathrm{P} 40$ and barl (5'-tctgcaccatcgtcaaccac$\left.3^{\prime}\right)$ and the primers P42 (5'-cctcggtctcacag- $\left.3^{\prime}\right)$ and bar2

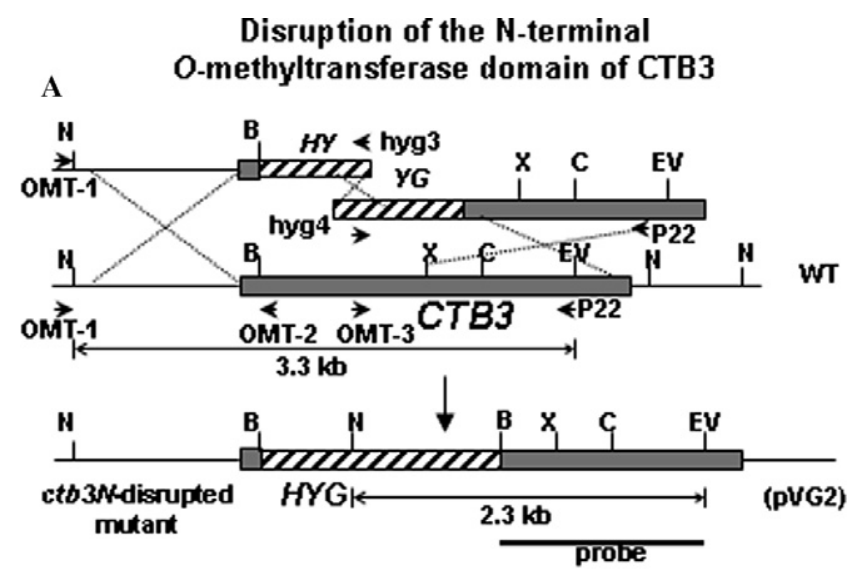

B

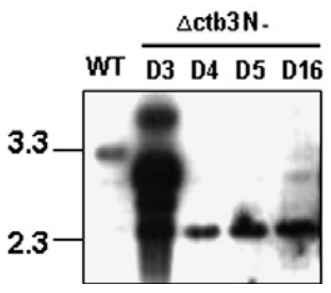

C $\frac{\Delta \text { ctb3N. }}{\text { D4 D5 D16 }}$

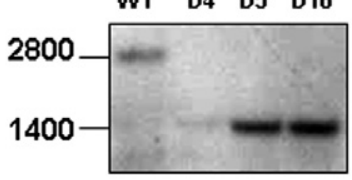

Fig. 1. Disruption of the N-terminal $O$-methyltransferase domain of CTB3 in Cercospora nicotianae. (A) Schematic illustration of a splithygromycin phosphotransferase $\mathrm{B}$ gene $(H Y G)$ marker used for the $5^{\prime}$-end $C T B 3$ disruption. Two truncated $C T B 3$ fragments fused with an overlapping $H Y G$ were amplified from the disruption construct pVG2 using primers (OMT-1/hyg3, P22/hyg4) and directly transformed into protoplasts of the C. nicotianae wild type (WT). Oligonucleotide primers (OMT-2 and OMT-3) used for cloning are also indicated. Restriction enzyme site abbreviations: B, BamHI; C, ClaI; EV, EcoRV; N, NcoI; X, XhoI. Note: drawing is not to scale. (B) Southern-blot analysis of genomic DNA from the wild type and four $\Delta$ ctb3N knockouts (D3, D4, D5, D16). Fungal DNA was digested with $E c o \mathrm{RV}$ and $N c o$ I, electrophoresed, blotted onto a nylon membrane, and hybridized to a $C T B 3$-specific probe as indicated. The membrane was washed at high stringency. Sizes of hybridizing bands are indicated in kilobase pairs $(\mathrm{kb})$. (C) Northern-blot analysis of total RNA isolated from the wild type and three $\Delta$ ctb3N knockouts (D4, D5, D16). Sizes of hybridizing bands are indicated in nucleotides (nt).

(5'-aaacccacgtcatgccagtt-3') from pCTB3/Bar6 were directly transformed into the $C$. nicotianae wild-type strain.

For genetic complementation, pCTB3G was co-transformed with the plasmid pBARKS1 carrying the $B A R$ gene responsible for bialaphos resistance under control of the Aspergillus nidulans trp $\mathrm{C}$ promoter (Pall and Brunelli, $1993)$ into a $\Delta$ ctb3-null mutant ( $\Delta$ ctb3N-D5). Transformants were selected on medium containing $50 \mu \mathrm{g} / \mathrm{ml}$ bialaphos (gluphosinate ammonium) (Fluka, Milwaukee, WI) and tested for cercosporin production on thin PDA plates as described previously (Chung, 2003). Fungal protoplasts were prepared and transformed using $\mathrm{CaCl}_{2}$ and polyethylene glycol (PEG) by previously described methods (Chung et al., 2002).

\subsection{Manipulation of nucleic acids}

Fungal DNA was isolated with a DNeasy Plant Mini kit (Qiagen, Valencia, CA). Fungal RNA was extracted with a TRIZOL RNA Isolator kit (Invitrogen). Standard 


\section{Disruption of the C-terminal FAD-dependent monooxygenase domain of CTB3}

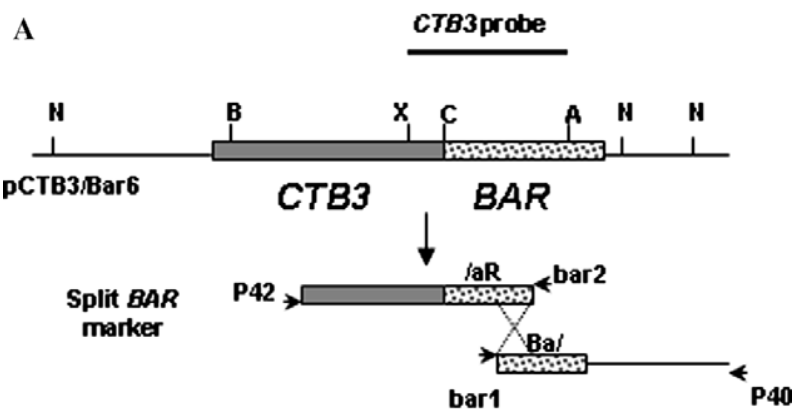

B

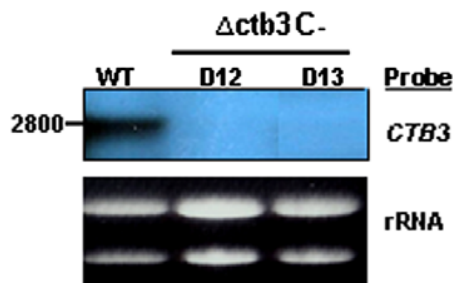

Fig. 2. Disruption of the $\mathrm{C}$ terminal FAD-dependent monooxygenase domain of CTB3 in Cercospora nicotianae. (A) Schematic illustration of pCTB3Bar6 plasmid containing a phosphinothricin acetyltransferase gene $(B A R)$ marker used for the $3^{\prime}$-end $C T B 3$ disruption. Two truncated $C T B 3$ fragments fused with an overlapped $B A R$ were amplified from the disruption construct pCTB3/Bar6 using primers (P42/bar-2, bar-1/P40) and directly transformed into protoplasts of the $C$. nicotianae wild type (WT). Restriction enzyme site abbreviations: A, AgeI; B, BamHI; C, ClaI; $\mathrm{N}, N c o \mathrm{I}$; X, XhoI. Note: drawing is not to scale. (B) Northern-blot analysis of total RNA isolated from the wild type and two $\Delta \mathrm{ctb} 3 \mathrm{C}$ knockouts (D12 and D13).

procedures were used for endonuclease digestion of DNA, electrophoresis, and Southern- and Northern-blot hybridizations (Sambrook and Russell, 2001). The hybridization probes were prepared by incorporating digoxigenin-11-dUTP (Roche) into the CTB3 DNA fragments by PCR with gene-specific primers (Chung et al., 2003c). Probe labeling, hybridization, post-hybridization washing and immunological detection of the probe using a CSPD lumigenic substrate for alkaline phosphatase were conducted following the manufacturer's instructions (Roche). Double-strand cDNA was synthesized from total RNA using a BD SMART cDNA synthesis kit (Clontech, Palo Alto, CA). CTB3 cDNA was obtained from cDNA pools by nested PCR. Two primers CTB3I (5'-cgtcctggtctcaat getaacatc- $\left.3^{\prime}\right)$ and P25 (5'ttagccaaggcgtcggcatcgact- $3^{\prime}$ ) were first used for amplification and the nested primer P22 was paired with CTB3I to amplify a $2.5-\mathrm{kb}$ cDNA fragment comprising the CTB3 gene with a TITANIUM Taq DNA polymerase (Clontech). The resulting fragment was cloned into the pGEM-T easy vector to yield pKAL41 for sequence analysis. All plasmids were propagated in competent Escherichia coli DH5 $\alpha$ bacterial cells and purified using a Wizard DNA purification kit (Promega).

\subsection{Fungal pathogenicity test}

Fungal inoculations were performed on detached tobacco (Nicotiana tabacum) leaves cultivar Burley 21 as previously described (Choquer et al., 2005). Toxin assays using tobacco cell suspensions were conducted as described by Daub (1982b). Briefly, cercosporin and other pigments extracted with ethyl acetate from agar plugs with mycelia were dried, dissolved in acetone and added to the 6-dayold tobacco cell suspensions $\left(10^{6}\right.$ cells $\left./ \mathrm{ml}\right)$. Cell cultures covered with or without aluminum foil were incubated on a rotary shaker $(140 \mathrm{rpm})$ at $32{ }^{\circ} \mathrm{C}$ under fluorescent lights at an intensity of $3.1 \times 10^{3} \mathrm{~J} / \mathrm{cm}^{2} / \mathrm{s}$. Cell viability was determined with the aid of a microscope after staining with $0.1 \%$ Evan's blue (Sigma).

\section{Results}

\subsection{Sequence analysis and characterization of C. nicotianae CTB3 gene}

Sequence analysis of a $C T B 1$-containing genomic clone pPKS-8 (Choquer et al., 2005) identified an additional putative gene, hereafter designated as CTB3. Coding sequences of $C T B 3$ and $C T B 1$ are separated by $846 \mathrm{bp}$ and are divergently transcribed. The promoter sequences of $C T B 3$ can be retrieved from the GenBank database under GenBank Accession No. AY649543. The CTB3 open reading frame (ORF) consists of 2613-bp nucleotides, interrupted by two small introns of 48 and $70 \mathrm{bp}$, and was predicted to encode a polypeptide of 871 amino acids (GenBank Accession No. DQ355149). Analysis of 640 nucleotides upstream from the ATG start codon of CTB3 identified three CAAT consensus sequences at positions $-282,-141$ and -37 , respectively.

A search of sequence databases suggested that the deduced amino acid sequence of $C T B 3$ translation product has two putative functional domains related to $O$-methyltransferases and FAD-dependent monooxygenases. The N-terminal amino acids (1-429) of CTB3 have strong similarity to numerous $S$-adenosyl-methionine (SAM)-dependent $O$-methyltransferases in bacteria and fungi (Table 1 and data not shown). Alignment of the $\mathrm{N}$-terminal amino acids of CTB3 with AFLO (formerly omtB) of Aspergillus is shown in supplementary Figure A. The N-terminal amino acids of CTB3 also have various degrees of similarity to AFLS (formerly AFLJ), a putative transcription co-regulator involved in aflatoxin biosynthesis in Aspergillus (supplementary Figure B). In contrast, the C-terminal amino acids (419-871) of CTB3 exhibit similarity to many putative FAD-dependent monooxygenases required for energy production in bacteria (supplementary Figure C).

\subsection{Targeted gene disruption and genetic complementation}

To determine if each domain of CTB3 is required for cercosporin biosynthesis, targeted gene disruption was 
Table 1

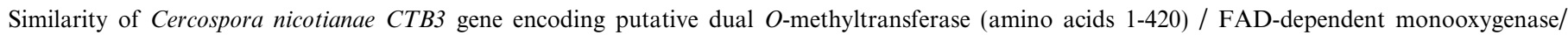
oxidoreductase (amino acids 421-871) domains with homologues to various fungal and bacterial species

\begin{tabular}{|c|c|c|c|c|c|c|}
\hline Species & Amino acids & Identity $(\%)$ & Similarity $(\%)$ & $E$-value & Accession No. & Putative function \\
\hline Gibberella zeae & 439 & 36 & 52 & $6 e-59$ & EAA69866 & Unknown \\
\hline Aspergillus nidulans & 459 & 30 & 45 & $4 e-39$ & EAA62575 & Unknown \\
\hline A. parasiticus & 386 & 36 & 55 & $9 e-25$ & AAS66016 & $O$-methyltransferase \\
\hline A. flavus & 386 & 35 & 51 & $2 \mathrm{e}-25$ & AF159789 & $O$-methyltransferase \\
\hline Magnaporthe grisea & 970 & 42 & 56 & 0 & EAA48769 & Unknown \\
\hline Neurospora crassa & 528 & 34 & 53 & $8 \mathrm{e}-32$ & EAA33703 & Unknown \\
\hline A. flavus & 438 & 26 & 45 & $4 e-25$ & AAS90004 & AFLJ, transcription enhancer \\
\hline A. nomius & 438 & 26 & 44 & $1 \mathrm{e}-24$ & AAS90052 & AFLJ \\
\hline Chromobacterium violaceum & 384 & 29 & 44 & $3 e-31$ & AAQ59500 & FAD-dependent monooxygenase \\
\hline Rubrobacter xylanophilus & 377 & 32 & 48 & $6 e-30$ & EAN36783 & FAD-dependent monooxygenase \\
\hline Bradyrhizobium sp. & 409 & 28 & 44 & $2 \mathrm{e}-25$ & EAP27500 & FAD-dependent monooxygenase \\
\hline Photorhabdus luminescens & 411 & 27 & 45 & $3 e-20$ & CAE14529 & Unknown \\
\hline
\end{tabular}

performed separately. A disruption vector pVG2 (Fig. 1A) containing a hygromycin phosphotransferase $\mathrm{B}$ gene $(H Y G)$ cassette flanked with CTB3 sequence on each side was first constructed to replace the $5^{\prime}$ end comprising the $\mathrm{N}$-terminal $O$-methyltransferase/AFLS domain of CTB3. In total, 18 of $32(\sim 56 \%)$ transformants recovered were unable to produce cercosporin on a thin PDA plate. The putative $\Delta$ ctb3 knockouts accumulated a yellow pigment.

Southern-blot analysis was performed to validate that the loss of cercosporin production was a consequence of the targeted gene replacement at the $5^{\prime}$ end of CTB3 (Fig. 1B). Genomic DNA from the wild-type strain and four $\Delta$ ctb3 disruptants $(\Delta \mathrm{ctb} 3 \mathrm{~N}-\mathrm{D} 3, \mathrm{D} 4, \mathrm{D} 5$ and D16) was cleaved with restriction enzymes $N c o$ I and EcoRV and hybridized with a $C T B 3$-specific probe. The results indicated that all $\triangle \mathrm{ctb} 3$ analyzed displayed a $C T B 3$ deletion in the $C$. nicotianae genome. As expected, the wildtype strain displayed a $3.3-\mathrm{kb} N c o \mathrm{I}-E c o \mathrm{RV}$ hybridizing band from the genomic DNA, whereas the $\Delta$ ctb3N disruptants contained a $2.3 \mathrm{~kb}$ hybridizing band due to the insertion of the $H Y G$ cassette in $C T B 3$ and the presence of an additional $N c o$ I site in the $H Y G$ gene cassette. In addition to the $2.3-\mathrm{kb}$ signal, three hybridizing bands of $\sim 5.0,3.0$ and $2.7 \mathrm{~kb}$ were also detected in DNA prepared from the $\Delta$ ctb3N-D3 disruptant (lane 2), likely resulting from the ectopic integrations of split marker fragments in the genome or incomplete digestion of genomic DNA. Northernblot analysis indicated that hybridization of total RNA from the wild-type strain with a $C T B 3$-specific probe identified a 2800-nucleotide (nt) transcript that was completely absent among three $\Delta \mathrm{ctb} 3 \mathrm{~N}$ strains (D4, D5, D16) (Fig. 1C). By contrast, a truncated transcript of approximate 1400 nucleotides in size was detected in RNA from the $\Delta c t b 3 N$ strains, verifying the disruption of $\Delta c t b 3 N$ strains indeed specifically occurred at the CTB3 locus.

Northern-blot analysis of RNA from the $\triangle \mathrm{ctb} 3 \mathrm{~N}$ disruptants identified a truncated $C T B 3$ transcript that might be able to produce a functional protein with monooxygenase activity. To determine the function of the C-terminal monooxygenase domain of $C T B 3$ in cercosporin biosynthesis, plasmid vector pCTB3/Bar6 carrying a phosphinothricin acetyltransferase gene $(B A R)$ cassette flanked by the $3^{\prime}$ region of $C T B 3$ was constructed for gene replacement (Fig. 2A). PCR fragments containing the split $B A R$ makers fused with $C T B 3$ sequences were amplified and used for transformation. Two transformants (designated $\Delta \mathrm{ctb} 3 \mathrm{C}-\mathrm{D} 12$ and D13) recovered from a medium containing gluphosinate ammonium were unable to produce cercosporin. Northern-hybridization analysis indicated that the 2800-nt CTB3 transcript was completely undetectable in the $\Delta$ ctb3C- D12 and D13 isolates (Fig. 2B), further validating the disruption occurred at the CTB3 locus. The $\triangle \mathrm{ctb} 3 \mathrm{C}$ disruptants failed to produce cercosporin but accumulated a yellow/brown pigment similar to the $\triangle \mathrm{ctb} 3 \mathrm{~N}$ disruptants. Thus, integration of the $H Y G$ or $B A R$ cassette in $C T B 3$ has completely disrupted the entire CTB3 ORF, resulting in $C$. nicotianae mutants with a lack of functional $O$-methyltransferases and FAD-dependent monooxygenases domains.

Genetic complementation was carried out to further verify the essential role of $C T B 3$ for cercosporin biosynthesis. A DNA fragment containing the full-length CTB3 gene and its promoter was co-transformed with pBARKS1 plasmid into protoplasts of the $\Delta$ ctb3N-D5 mutant. In total, 7 of $23(30 \%)$ strains recovered produced large amounts of cercosporin comparable to that of wild type (Table 2).

To determine if mutants disrupted in $C T B 1$ (encoding a polyketide synthase) or CTB3 would complement each other for cercosporin biosynthesis by substrate cross feeding, the $\Delta$ ctb1 and $\Delta$ ctb3 knockouts were co-cultured on PDA. Complementation was observed when a $\Delta$ ctbl disruptant was paired with the $\Delta \mathrm{ctb} 3 \mathrm{~N}$ or $\Delta \mathrm{ctb} 3 \mathrm{C}$ disruptants by formation of a distinct red band where the mycelia of the mutant colonies were in contact (Fig. 3A). Formation of cercosporin also was observed when cellophane was placed between two colonies. However, no cercosporin was observed when the $\Delta \mathrm{ctb} 3 \mathrm{~N}$ disruptants and the $\Delta \mathrm{ctb} 3 \mathrm{C}$ disruptants were grown together (data not shown).

\subsection{Detection and quantification of cercosporin}

Production of cercosporin (a distinct red pigment) by the wild-type strain, the $\Delta$ ctb3 disruptants and the complemented strains was first assessed by growing the fungal 
Table 2

Production of cercosporin by the Cercospora nicotianae wild-type strain $(\mathrm{CnA})$, the $c t b 3$ mutants disrupted in the $\mathrm{N}$-terminus $(\Delta \mathrm{ctb} 3 \mathrm{~N})$, and C-terminus $(\triangle \mathrm{ctb} 3 \mathrm{C})$, and the $C T B 3$-complemented strains (T5C11 and T5C12) under continuous light (LT) or darkness (DK)

\begin{tabular}{llc}
\hline Isolates & Treatment & $\begin{array}{c}\text { Cercosporin production } \\
(\text { nmol/agar plug) }\end{array}$ \\
\hline CnA & LT & $196.2 \pm 58.6$ \\
$\Delta$ ctb3N-D3 & DK & $3.7 \pm 0.8$ \\
& LT & $11.0 \pm 4.4$ \\
$\Delta$ ctb3N-D4 & DK & $1.4 \pm 0.6$ \\
& LT & $44.6 \pm 4.8$ \\
$\Delta$ ctb3N-D5 & DK & $1.2 \pm 0.4$ \\
& LT & $50.9 \pm 14.7$ \\
$\Delta$ ctb3N-D16 & DK & $1.4 \pm 0.9$ \\
& LT & $24.3 \pm 11.4$ \\
T5C11 & DK & $1.4 \pm 0.6$ \\
& LT & $229.7 \pm 41.3$ \\
T5C12 & DK & $6.6 \pm 2.9$ \\
& LT & $270.3 \pm 84.9$ \\
$\Delta$ ctb3C-D12 & DK & $5.2 \pm 1.9$ \\
& LT & $24.6 \pm 7.9$ \\
$\Delta$ ctb3C-D13 & DK & $0.6 \pm 0.2$ \\
& LT & $16.6 \pm 3.2$ \\
& DK & $1.0 \pm 0.4$ \\
\hline
\end{tabular}

${ }^{\text {a }}$ Fungal mycelium of $C$. nicotianae strains was grown on thin PDA plates for 7 days. Cercosporin was extracted with $5 \mathrm{~N} \mathrm{KOH}$ and quantified by measuring absorbance of the extract at $480 \mathrm{~nm}$. Control consisted of five PDA plugs extracted with $5 \mathrm{~N} \mathrm{KOH}$. Data are the means of three different experiments with five replicates of each isolate. Data shown \pm standard error of the means.

strains on thin PDA under continuous light (Fig. 3B) or in complete darkness. Cercosporin and potential biosynthetic intermediates were then extracted from mycelial plugs with $5 \mathrm{~N} \mathrm{KOH}$. As shown in Fig. 3C, the extract from the wildtype strain produced a green color after soaking in $\mathrm{KOH}$ solution, whereas the extract from the $\Delta \mathrm{ctb} 3$ disruptants yielded an orange color. The amounts of cercosporin in the extract were quantified by measuring absorbance at $480 \mathrm{~nm}$ (Table 2). All extracts of fungal isolates grown in the dark had very low absorbance values, similar to the controls containing agar plugs alone. The wild-type strain produced high levels of cercosporin when grown on PDA under light. Spectrophotometric scanning of the $\mathrm{KOH}$ extract from the wild-type strain, the $\Delta$ ctb3 disruptants, and the complemented strains also revealed a marked difference in the respective absorption spectrum. The $\mathrm{KOH}$ extract of wild type had a strong absorbance at $480 \mathrm{~nm}$ and two small peaks at 600 and $640 \mathrm{~nm}$, as reported by Sollod et al., 1992). By contrast, the $\mathrm{KOH}$ extract of the $\Delta$ ctb3 disruptants had no absorbance at $480 \mathrm{~nm}$.

To further confirm the inability for cercosporin production by the ctb3 knockouts, fungal cultures were extracted with ethyl acetate and the extracts were analyzed by TLC and HPLC. As shown in Fig. 3D, the wild-type strain and the complemented strains produced a red pigment at $R_{f} 0.7$, typical of cercosporin, whereas the $\Delta$ ctb3-disrupted mutants produced a yellow pigment at $R_{f} 0.9$. The yellow pigment gradually converted to a dark brown color on TLC plates (Fig. 3D). HPLC analysis also confirmed that
A
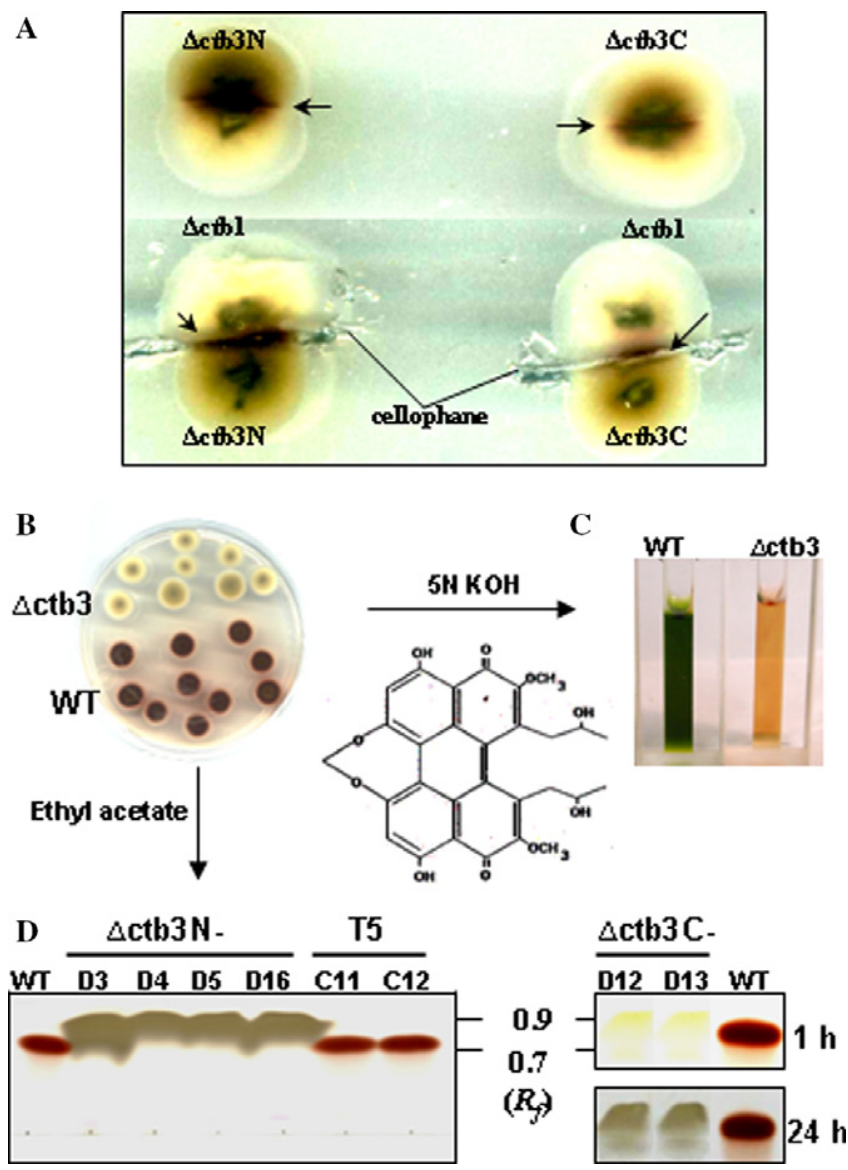

Fig. 3. Characterization of cercosporin produced by the wild type (WT) and a pigment produced by the $\Delta \mathrm{ctb} 3$ disruptant of Cercospora nicotianae. (A) Complementation of cercosporin production by pairing the $\Delta$ ctb1 with $\Delta$ ctb3 disruptants as indicated on a PDA plate. (B) Production of cercosporin and other pigments by the wild type and the $\Delta$ ctb3 disruptants of $C$. nicotianae on potato dextrose agar plates. Accumulation of cercosporin is indicated by the red pigment. The chemical structure of cercosporin also is shown. (C) Reaction of cercosporin from the wild type and the pigment from the $\Delta$ ctb3 disruptants with $5 \mathrm{~N} \mathrm{KOH}$. (D) Thinlayer chromatography (TLC) analysis of cercosporin production by the wild-type (WT) strain, the $\Delta \mathrm{ctb} 3 \mathrm{~N}$ terminal disruption mutants $(\Delta \mathrm{ctb} 3 \mathrm{~N}$ D3, D4, D5, D16), the CTB3-complemented strains (T5C11, T5C12), and the $\Delta$ ctb3 $\mathrm{C}$ terminal disruption mutants of $C$. nicotianae. Cercosporin extracted from agar plugs was dissolved in acetone, spotted onto a silica gel plate, and separated with ethyl acetate:hexane:methanol: $\mathrm{H}_{2} \mathrm{O}$ $(6: 4: 1.5: 1, v / v)$. Cercosporin produced by the wild type and the complemented strains was detected as a red pigment with mobility at $R_{f} 0.7$. By contrast, the $\Delta$ ctb3-disrupted mutants produced a yellow/brown pigment at $R_{f} 0.9$. The pigment produced by the $\Delta$ ctb3 disruptants was yellowish (right upper panel) and gradually changed to a brown color (right bottom panel). (For interpretation of the references to color in this figure legend, the reader is referred to the web version of this paper).

no measurable cercosporin was produced by the $\Delta \mathrm{ctb} 3$ disruptants (data not shown). The yellow/brown pigment was completely undetectable when the $\Delta$ ctb3 disruptants were grown in darkness. Collectively, we concluded that the $\Delta$ ctb3 disruptants are completely defective in cercosporin accumulation.

To determine if the yellow/brown pigment extracted from cultures of the $\Delta \mathrm{ctb} 3$ disruptants is toxic, tobacco cell 
suspensions were treated with the extracts from the wildtype strain and $\Delta$ ctb3 disruptants, and incubated under continuous light or in complete darkness. The results indicated that the yellow pigment extracted from the cultures of the $\Delta \mathrm{ctb} 3$ disruptants was no longer toxic to tobacco cells compared to cercosporin produced by the wild type (Fig. 4).

Marked deficiency in cercosporin production was the only phenotype altered in the $\Delta$ ctb3 disruptants. Similar to the $\Delta$ ctb1 knockouts (Choquer et al., 2005), all $\Delta$ ctb3 disruptants exhibited growth similar to the wild-type strain on the medium containing exogenous cercosporin $(10 \mu \mathrm{M})$ or other photosensitizing compounds (eosine Y, methylene blue or toluidine blue) under continuous light (data not shown), indicating that $C T B 3$ plays no role in cercosporin or singlet oxygen resistance. The $\Delta \mathrm{ctb} 3$ disruptants exhibited normal growth on various media and maintained normal conidiation on V8 juice agar.

\subsection{Expression and regulation of CTB3}

To test if accumulation of the CTB3 transcript in $C$. nicotianae is coordinately regulated by light and medium composition suited for cercosporin production, the wildtype $C$. nicotianae was grown in either continuous light or continuous darkness on PDA or complete medium (CM). Total RNA purified from these cultures was hybridized to a $C T B 3$-specific probe. As shown in Fig. 5A, high levels of the 2800-nt CTB3 transcript were detected in RNA samples prepared from fungal cultures grown on PDA under continuous light, conducive conditions for cercosporin production and accumulation (Fig. 5B). By contrast, accumulation of $C T B 3$ transcript and cercosporin were markedly decreased when the fungus was grown on $\mathrm{CM}$ under continuous light. The CTB3 transcript and

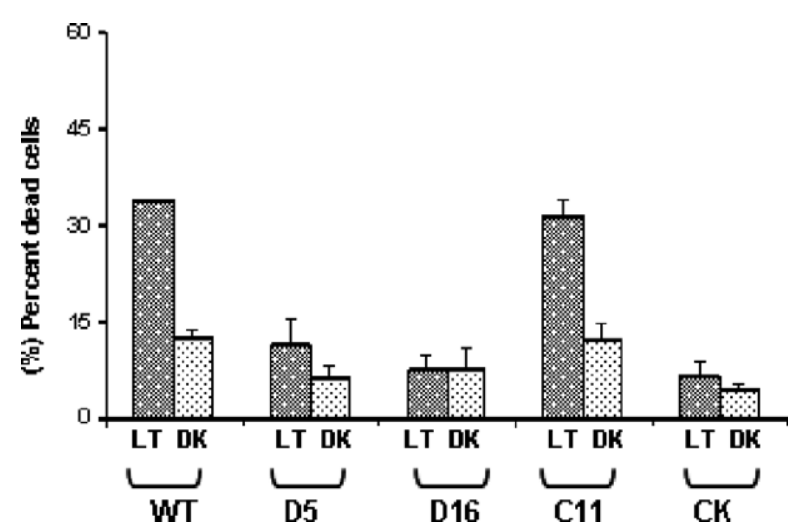

Fig. 4. Viability of tobacco suspension cells treated with pigments produced by the wild type (WT), two ctb3-disrupted mutants $(\Delta \mathrm{ctb} 3 \mathrm{~N}$ D5, D16), and a complemented strain (T5C11) of Cercospora nicotianae, and the acetone control (CK) under continuous light (LT) or in complete darkness (DK). Tobacco cell suspensions were mixed with the test compounds and incubated at $32{ }^{\circ} \mathrm{C}$ for $5 \mathrm{~h}$. Cell viability was evaluated after staining with $0.1 \%$ Evan's blue. Data are the means of three replicates of each treatment.
A

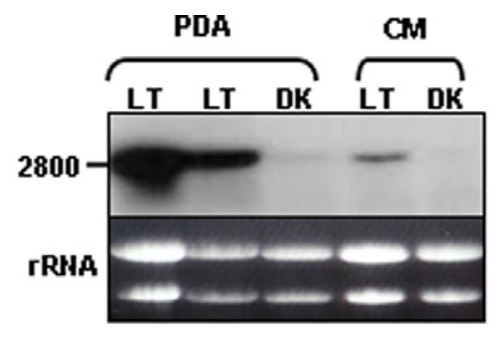

B
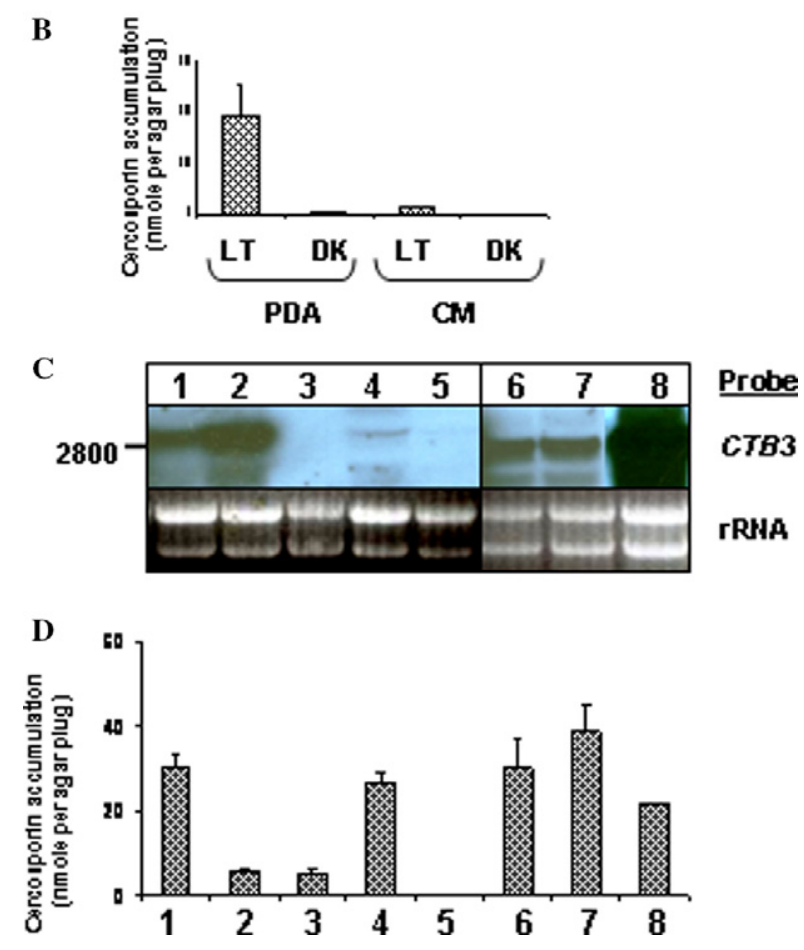

Fig. 5. Differential expression of the CTB3 gene and accumulation of cercosporin by the Cercospora nicotianae wild type. (A) Northern-blot analysis of $C T B 3$ expression in the $C$. nicotianae wild type grown on potato dextrose agar (PDA) or complete medium $(\mathrm{CM})$ under continuous light (LT) or darkness (DK). Fungal RNA was isolated, electrophoresed in a formaldehyde-containing gel, blotted to a nylon membrane, and hybridized to a $C T B 3$-specific probe as indicated in Fig. 1A. Ethidium bromide-stained rRNA is shown for loading of the samples. Sizes of hybridizing bands are indicated in nucleotides. (B) Accumulation of cercosporin by the $C$. nicotianae wild type. The fungus was grown on PDA or CM plates under continuous light (LT) or darkness (DK) for 5 days, and cercosporin was extracted with $5 \mathrm{~N} \mathrm{KOH}$ and quantified by absorbance at $480 \mathrm{~nm}$. Data shown are the means and standard errors of two different experiments with five replicates of each treatment. (C) Northern-blot analysis of CTB3 expression in the C. nicotianae wild type grown on complete medium ( $\mathrm{CM}$ with glucose and calcium nitrate as a sole carbon and nitrogen source, respectively) (lane 1), mannitol as a sole carbon source (lane 2), ammonium chloride as a sole nitrogen source (lane 3), no nitrogen added in CM (lane 4), and "shift experiment" (The fungus was grown on PDA for 5 days and shifted to CM) (lane 5), and on PDA at pH 4.0 (lane 6), pH 5.0 (lane 7), and pH 7.0 (lane 8) under continuous light. (D) Accumulation of cercosporin by the C. nicotianae wild type grown on media as indicated above. Accumulation of cercosporin was not determined when the fungus was grown on PDA for 5 days and shifted to CM (lane 5).

cercosporin were undetectable or barely detectable when the fungus was grown on either PDA or CM in continuous darkness. Thus, expression of the CTB3 gene appeared to 
coincide well with cercosporin accumulation in response to light and medium as with the CTBI transcript (Choquer et al., 2005).

Expression of the CTB3 gene in culture was further investigated to determine if any ingredients in $\mathrm{CM}$ may repress accumulation of the $C T B 3$ gene transcript. Northern-blot hybridization indicated that substitution of glucose with mannitol as a sole carbon source in $\mathrm{CM}$ markedly increased accumulation of the CTB3 gene transcript (Fig. 5C, lanes 1 and 2), but failed to support increased production of cercosporin (Fig. 5D). Substitution of calcium nitrate with ammonium chloride as a sole nitrogen source in $\mathrm{CM}$, however, completely blocked expression of $C T B 3$ and production of cercosporin (lane 3). Omission of the nitrogen from $\mathrm{CM}$ also decreased expression of the $C T B 3$ gene (lane 4), but remained normal cercosporin production. The CTB3 transcript was completely undetected when fungal mycelium grown on PDA for 5 days was shifted to CM (lane 5). Expression of the CTB3 gene appeared strongest at $\mathrm{pH} 7.0$ when the fungus was grown on the permissive medium (PDA) and occurred to a much lesser extent at $\mathrm{pH} 4$ and 5 (lanes 6-8). However, there was no strong correlation between cercosporin production and accumulation of the $C T B 3$ transcript on PDA with various $\mathrm{pH}$.

\subsection{Pathogenicity tests}

Previously, we have shown that disruption of the $C T B 1$ gene resulted in mutants completely defective in cercosporin production and markedly reduced in lesion development on tobacco cv. Burley 21 (Choquer et al., 2005). The $\Delta$ ctb1 disruptants did not accumulate any pigments. In contrast, disruption of the $C T B 3$ gene resulted in strains that accumulated a yellow/brown pigment instead of the red cercosporin. Those mutants were inoculated onto detached tobacco leaves cv. Burley 21. Similar to the $\Delta$ ctb1 disruptants (Choquer et al., 2005), the $\Delta$ ctb3 disruptants (D5, D8, D16) incited fewer necrotic lesions on tobacco leaves compared to those induced by the wild-type strain, whereas the CTB3 complemented strain (T5C11) produced necrotic lesions comparable to the wild type (Fig. 6).

\section{Discussion}

In the present study, we identified a $C$. nicotianae $C T B 3$ gene located immediately adjacent to the $C T B 1$ gene and provided experimental evidence that CTB3 encodes an enzyme for cercosporin biosynthesis. Targeted gene replacement and genetic complementation unambiguously confirmed the involvement of $C T B 3$ in cercosporin biosynthesis in C. nicotianae. Furthermore, sequence analysis of the surrounding DNA fragments obtained by chromosome walking outward from the $C T B 1$ and $C T B 3$ genes, allowed us to identify several putative ORFs with amino acid similarities to a wide range of $O$-methyltransferases, major facilitator superfamily (MFS) transporters, and $\mathrm{Cys}_{6} \mathrm{Zn}_{2}$

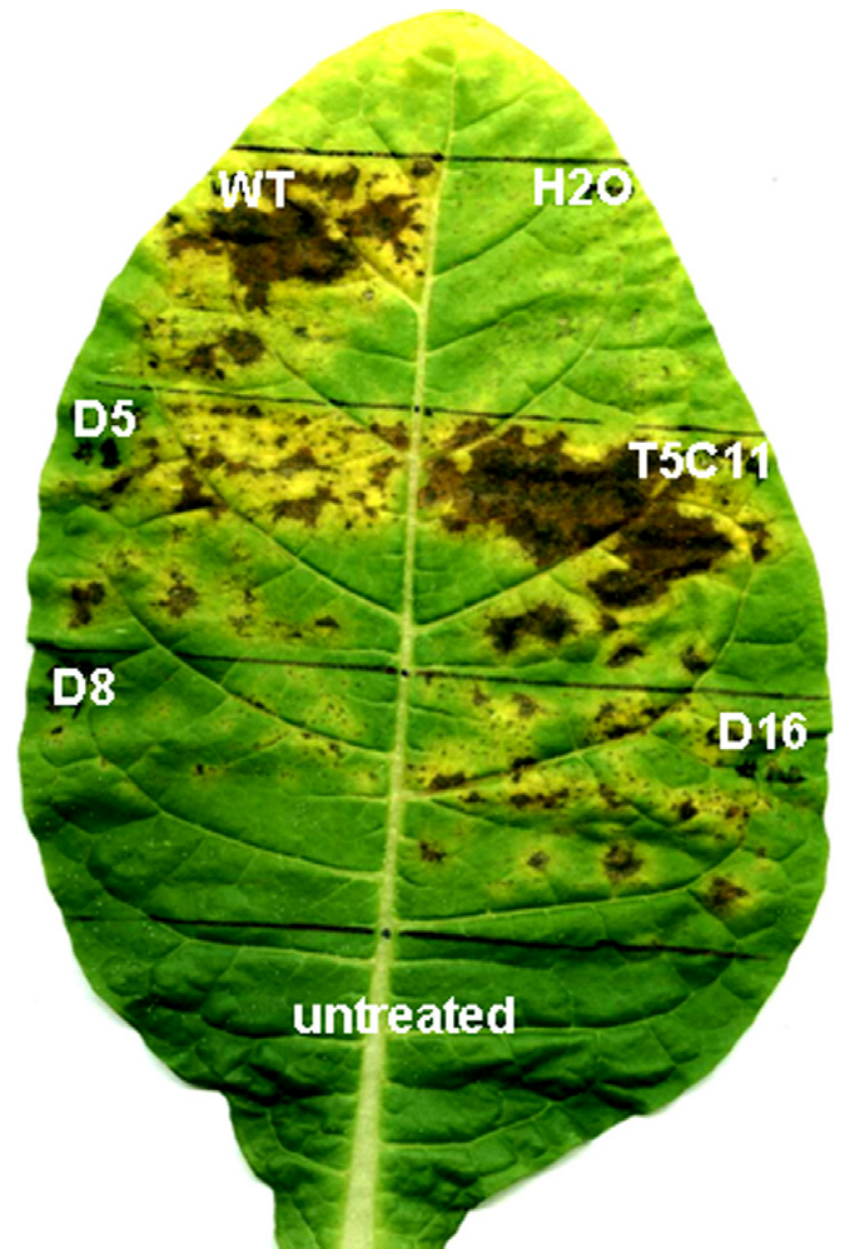

Fig. 6. Pathogenicity assay using detached tobacco leaves cv. Burley 21. The Cercospora nicotianae wild type (WT), $\Delta \mathrm{ctb} 3$-knockout mutants $(\Delta \mathrm{ctb} 3 \mathrm{~N}-\mathrm{D} 5, \mathrm{D} 8, \mathrm{D} 16)$ and $C T B 3$-complemented strain $(\mathrm{T} 5 \mathrm{C} 11)$ were grown on V8 juice agar for $7-12$ days at $20^{\circ} \mathrm{C}$ under continuous light. The concentration of conidia was adjusted to $5 \times 10^{4}$ conidia $/ \mathrm{ml}$ and rubbed onto wounded tobacco leaves with cotton swabs. The inoculated leaves were then kept in a moist chamber under fluorescent light.

binuclear cluster motif-containing transcriptional activators in the database, respectively (unpublished data). Such proteins are required for the accumulation of many fungal secondary metabolites, including aflatoxin, fumonisin, sterigmatocystin, and trichothecene (Alexander et al., 1999; Brown et al., 1996; Proctor et al., 2003; Yu et al., 2004). Thus, the results suggest that the genes required for cercosporin production likely reside in cluster.

The deduced CTB3 polypeptide has two putative functional domains with $O$-methyltransferase and FAD-dependent monooxygenase at $\mathrm{N}$ and $\mathrm{C}$ termini, respectively. The finding that the CTB3 translation product contains dual functional domains is highly unusual. The functions of $O$-methyltransferase and FAD-dependent monooxygenase are often encoded by separate genes in an organism, with one exception of a hypothetical, uncharacterized protein (GenBank Accession No. EAA48769) from the sequenced genome of Magnaporthe grisea. Protein alignments indicated that CTB3 and the $M$. grisea hypothetical protein have 
similar structures, sizes and organizations with dual $O$ methyltransferase and FAD-dependent monooxygenase domains (data not shown). A protein with multiple functional domains also was observed in other fungal species. Fusion of the cytochrome P450 monooxygenase and NADPH-dependent cytochrome reductase functions in a single protein has also been found in the FUM6 involved in fumonisin biosynthesis in $F$. verticilloides (Seo et al., 2001). The EQIS containing a PKS-nonribosomal peptide synthase (NRPS) hybrid was found to be involved in equisetin biosynthesis in Fusarium heterosporum (Sims et al., 2005). Similarly, the alt5 gene encoding a polyketide synthase also contains a $C$-methyltransferase domain required for decaketide alternapyrone biosynthesis in Alternaria solani (Fujii et al., 2005).

The backbone of cercosporin is derived from the condensations of acetate and malonate to form polyketomethylene chains, most likely via the polyketide biosynthetic pathway (Okubo et al., 1975). Cercosporin contains two methyl groups at positions $\mathrm{C} 2$ and $\mathrm{C} 11$, and methylation has also been proposed to be involved in its biosynthesis (Okubo et al., 1975). Thus, the CTB3 translation product may likely catalyze the addition of one or two methyl groups into the cercosporin backbone (Fig. 3).

The C-terminus (a.a. 419-871) of CTB3 resembles many putative FAD-dependent monooxygenases from a variety of organisms, particularly in bacteria (supplementary Figure C). Members of this group of enzymes include phenol hydroxylase from Trichosporon cutaneum (GenBank Accession nos. 1FOH_A) and Ralstonia pickettii (GenBank Accession No. Q01551), kynurenine 3-monooxygenase for biosynthesis of nicotinic acid (GenBank Accession No. P38169), and putative squalene epoxidase from Arabidopsis thaliana (GenBank Accession No. AAC32430). The FAD-dependent monooxygenase domain of CTB3 likely catalyzes hydroxylation of the cercosporin backbone. Likewise, disruption of the FAD-dependent monooxygenase domain alone in $C$. nicotianae also interfered with cercosporin biosynthesis.

Although the N-terminus of CTB3 comprises an $O$ methyltransferase domain, database search revealed that the amino acids translated from the same frame also have similarity ( $26 \%$ identity and $48 \%$ similarity) to AFLS (formerly AFLJ). AFLS has been shown to be involved in aflatoxin biosynthesis by interacting with a zinc finger transcription factor, AFLR, to activate aflatoxin structural genes in A. parasiticus (Chang, 2003). Whether or not the $\mathrm{N}$-terminus of CTB3 acts as a transcription co-regulator as proposed for AFLS awaits further analysis.

Biosynthesis of secondary metabolites such as aflatoxin, sterigmatocystin, trichothecene, penicillin, and fumonisin in fungi is often regulated by various environmental conditions, developmental processes and cell differentiation (Calvo et al., 2002). Similarly, production of cercosporin by Cercospora spp. is primarily induced by light and affected by medium composition such as carbon and nitrogen sources and $\mathrm{pH}$ in the culture medium
(Daub and Ehrenshaft, 2000; Ehrenshaft and Upchurch, 1993; Jenns et al., 1989). In general, C. nicotianae accumulated high amounts of cercosporin when grown on potato dextrose agar (PDA) under continuous light, but produced no cercosporin when grown in continuous darkness. In a prior study, we have shown that the light- or medium-induced $C T B 1$ gene transcript accumulation was correlated with light- or medium-induced cercosporin production (Choquer et al., 2005). Northern-hybridization analysis conducted in the present study also revealed that the $C T B 3$ gene transcript was expressed under conditions highly favorable for cercosporin production by $C$. nicotianae. However, change of the carbon or nitrogen source in CM slightly influenced accumulation of the CTB3 transcript, but did not enhance cercosporin accumulation. Comparative promoter analysis using TRES (Transcription Regulation Element Search; http//:bioportal.bic.nus.edu.sg/tres) failed to identify the CREA (carbon regulatory protein) (Dowzer and Kelly, 1991) binding site in the promoter region of CTB3. However, an AREA (nitrogen regulatory protein) (Marzluf, 1997) and a PACC ( $\mathrm{pH}$ regulatory protein) (Espeso et al., 2000) conserved sequence was found in the CTB3 promoter region (data not shown). Transfer of fungal mycelia from PDA to CM completely abolished accumulation of the $C T B 3$ transcript and cercosporin, indicating the presence of inhibitors for cercosporin biosynthesis in CM. Further, we observed a significant reduction of cercosporin accumulation when the fungus was grown on PDA buffered with citric acid-phosphate solution. As shown in Fig. 5, the amounts $(\sim 40 \mathrm{nmol} / \mathrm{plug})$ of cercosporin accumulated on the PDA buffered with citric acid and phosphate solution were as much as 5-fold lower than those ( 200 nmole/plug) accumulated on regular PDA (Difco; pH 5.6).

The $\Delta$ ctb1 disruptants defective in the polyketide synthase failed to accumulate any detectable pigments in culture (Choquer et al., 2005). In contrast, disruption of $C T B 3$ with the $H Y G$ or $B A R$ cassette in C. nicotianae generated fungal mutants that accumulated a yellow/brown pigment with different mobility from cercosporin on TLC plates when grown on PDA in continuous light. The $\Delta \mathrm{ctb} 3$ disruptants, however, failed to accumulate any pigment when grown in continuous darkness, indicating that the yellow/brown pigment is regulated by light as well. Assays using tobacco suspension cells revealed that the yellow/ brown compound extracted from the $\Delta$ ctb3 disruptants was not toxic to tobacco cells. Whether or not the yellow/brown pigment accumulated by the $\Delta$ ctb3 knockouts represents an intermediate for cercosporin biosynthesis awaits further structural investigation. Complementation of cercosporin production was achieved when the $\Delta \mathrm{ctb} 3$ disruptants were paired with the $\Delta \mathrm{ctb} 1$ disruptants on PDA even in the presence of cellophane barriers. The results indicated that complementation between paired mutants was the result of cross feeding rather than diploidization, genetic exchange, heterokaryon formation, or 
mutant reversion. Judging from all available data, the yellow/brown pigment produced by the $\Delta$ ctb3 disruptants is likely an intermediate for cercosporin biosynthesis.

Pathogenicity assays using detached tobacco cv. Burley 21 leaves revealed that, as with the $\Delta \mathrm{ctb} 1$ disruptants (Choquer et al., 2005), the $\Delta$ ctb3-disrupted mutants incited less necrotic lesions compared to those of wild type, further confirming the important role of cercosporin in fungal virulence.

In summary, $C T B 3$ is tightly linked with $C T B 1$ and is also essential for cercosporin production. This is the first report describing the possible clustering of genes involved in cercosporin biosynthesis. We have obtained 10 putative ORFs in a span of $34 \mathrm{~kb}$ sequences that might be involved in cercosporin biosynthesis and regulation in C. nicotianae. Functional determination of the remaining genes that closely link to $C T B 1$ and $C T B 3$ is currently in progress.

\section{Acknowledgments}

We thank D.J. Lewandowski for providing tobacco plants and cell cultures, H.Q. Chen for technical assistance and S. Gowda and two anonymous reviewers for helpful comments. This research was supported by the Florida Agricultural Experiment Station.

\section{Appendix A. Supplementary data}

Supplementary data associated with this article can be found, in the online version, at doi:10.1016/j.fgb. 2006.08.005.

\section{References}

Abe, Y., Ono, C., Hosobuchi, M., Yoshikawa, H., 2002. Functional analysis of $m l c R$, a regulatory gene for ML-236B (compactin) biosynthesis in Penicillium citrinum. Mol. Gen. Genomics 268, 352361.

Ahn, J.H., Walton, J.D., 1996. Chromosomal organization of TOX2, a complex locus controlling host-selective toxin biosynthesis in Cochliobolus carbonum. Plant Cell 8, 887-897.

Alexander, N.J., McCormick, S.P., Hohn, T.M., 1999. TRI12, a trichothecene efflux pump from Fusarium sporotrichioides: Gene Isolation and Expression in Yeast. Mol. Gen. Genet. 261, 977-984.

Brown, M.P., Brown-Jenco, C.S., Payne, G.A., 1999. Genetic and molecular analysis of aflatoxin biosynthesis. Fungal Genet. Biol. 26, $81-98$.

Brown, D.W., Yu, J.H., Keller, H.S., Fernandes, M., Nesbitt, T.C., Keller, N.P., Adams, T.H., Leonard, T.J., 1996. Twenty-five coregulated transcripts define a sterigmatocystin gene cluster in Aspergillus nidulans. Proc. Natl. Acad. Sci. USA 93, 1418-1422.

Callahan, T.M., Rose, M.S., Meade, M.J., Ehrenshaft, M., Upchurch, R.G., 1999. CFP, the putative cercosporin transporter of Cercospora kikuchii, is required for wild type cercosporin production, resistance, and virulence on soybean. Mol. Plant-Microbe Interact. 12, 901-910.

Calvo, A.M., Wilson, R.A., Bok, J.W., Keller, N.P., 2002. Relationship between secondary metabolism and fungal development. Microbiol. Molec. Biol. Rev. 66, 447-459.

Chang, P.K., 2003. The Aspergillus parasiticus protein AFLJ interacts with the aflatoxin pathway-specific regulator AFLR. Mol. Gen. Genomics 268, 711-719.
Choquer, M., Dekkers, K.A., Chen, H.Q., Cao, L., Ueng, P.P., Daub, M.E., Chung, K.R., 2005. The CTB1 gene encoding a fungal polyketide synthase is required for cercosporin biosynthesis and fungal virulence of Cercospora nicotianae. Mol. Plant-Microbe Interact. 18, 468-476.

Chung, K.R., 2003. Involvement of calcium/calmodulin signaling in cercosporin toxin biosynthesis by Cercospora nicotianae. Appl. Environ. Microbiol. 69, 1187-1196.

Chung, K.R., Jenns, A.E., Ehrenshaft, M., Daub, M.E., 1999. A novel gene required for cercosporin toxin resistance in the fungus, Cercospora nicotianae. Mol. Gen. Genet. 262, 382-389.

Chung, K.R., Shilts, T., Li, W., Timmer, L.W., 2002. Engineering a genetic transformation system for Colletotrichum acutatum, the causal fungus of lime anthracnose and postbloom fruit drop. FEMS Microbiol. Lett. 213, 33-39.

Chung, K.R., Daub, M.E., Kuchler, K., Schüller, C., 2003a. The CRG1 gene required for resistance to the singlet oxygen-generating cercosporin toxin in Cercospora nicotianae encodes a putative fungal transcription factor. Biochem. Biophys. Res. Comm. 302, 302-310.

Chung, K.R., Ehrenshaft, M., Wetzel, D.K., Daub, M.E., 2003 b. Cercosporin toxin deficient mutants by plasmid tagging in the asexual fungus Cercospora nicotianae. Mol. Genet. Genomics 270, 103-113.

Chung, K.R., Daub, M.E., Ehrenshaft, M., 2003c. Expression of the cercosporin toxin resistance gene $(C R G 1)$ as a discistronic mRNA in the filamentous fungus Cercospora nicotianae. Curr. Genet. 43, 415424 .

Daub, M.E., 1982a. Peroxidation of tobacco membrane lipids by the photosensitizing toxin, cercosporin. Plant Physiol. 69, 1361-1364.

Daub, M.E., 1982b. Cercosporin, a photosensitizing toxin from Cercospora species. Phytopathology 72, 370-374.

Daub, M.E., Briggs, S.P., 1983. Changes in tobacco cell membrane composition and structure caused by the fungal toxin, cercosporin. Plant Physiol. 71, 763-766.

Daub, M.E., Ehrenshaft, M., 2000. The photoactivated Cercospora toxin cercosporin: Contributions to plant disease and fundamental biology. Annu. Rev. Phytopathol. 38, 461-490.

Daub, M.E., Hangarter, R.P., 1983. Production of singlet oxygen and superoxide by the fungal toxin, cercosporin. Plant Physiol. 73, 855857.

Daub, M.E., Herrero, S., Chung, K.R., 2005. Photoactivated perylenequinone toxins in fungal pathogenesis of plants. FEMS Microbiol. Lett. 252, 197-206.

Dowzer, C.D., Kelly, J.M., 1991. Analysis of the creA gene, a regulator of carbon catabolite repression in Aspergillus nidulans. Mol. Cell. Biol. 11, 5701-5709.

Ehrenshaft, M., Upchurch, R.G., 1993. Host protein(s) induces accumulation of the toxin cercosporin and mRNA in a phytopathogenic strain of Cercospora kikuchii. Physiol. Plant Pathol. 79, 157-164.

Espeso, E.A., Arst Jr., H.N., 2000. On the mechanism by which alkaline $\mathrm{pH}$ prevents expression of an acid-expressed gene. Mol. Cell. Biol. 20, 3355-3363.

Foote, C.S., 1976. Photosensitized oxidation and singlet oxygen: Consequences in Biological Systems. In: Pryor, W.A. (Ed.), Free Radicals in Biology, II. Academic Press, New York, pp. 85-133.

Fore, S.A., Daub, M.E., Beute, M.K., 1988. Phytotoxic substances produced by some isolates of Cercospora arachidicola are not cercosporin. Phytopathology 78, 1082-1086.

Fujii, I., Yoshida, N., Shimomaki, S., Oikawa, H., Ebizuka, Y., 2005. An iterative type I polyketide synthase PKSN catalyzes synthesis of the decaketide alternapyrone with regio-specific octa-methylation. Chem. Biol. 12, 1301-1309.

Gardiner, D.M., Cozijnsen, A.J., Wilson, L.M., Pedras, M.S.C., Howlett, B.J., 2004. The sirodesmin biosynthetic gene cluster of the plant pathogenic fungus Leptosphaeria maculans. Mol. Microbiol. 53, 13071318.

Hohn, T.M., McCormick, S.P., Desjardins, A.E., 1993. Evidence for a gene cluster involving trichothecene-pathway biosynthetic genes in Fusarium sporotrichioides. Curr. Genet. 24, 291-295. 
Ito, T., 1981. Dye binding and photodynamic action. Photochem. Photobiol. 33, 947-955.

Jenns, A.E., Daub, M.E., 1995. Characterization of mutants of Cercospora nicotianae sensitive to the toxin cercosporin. Phytopathology 85 , 906-912.

Jenns, A.E., Daub, M.E., Upchurch, R.G., 1989. Regulation of cercosporin accumulation in culture by medium and temperature manipulation. Phytopathology 79, 213-219.

Keller, N.P., Hohn, T.M., 1997. Metabolic pathway gene clusters in filamentous fungi. Fungal Genet. Biol. 21, 17-29.

Lu, S., Lyngholm, L., Yang, G., Bronson, C., Yoder, O.C., Turgeon, B.G., 1994. Tagged mutations at the Tox1 locus of Cochliobolus heterostrophus by restriction enzyme-mediated integration. Proc. Natl. Acad. Sci. USA. 91, 12649-12653.

Marzluf, G.A., 1997. Genetic regulation of nitrogen metabolism in the fungi. Microbiol. Mol. Biol. Rev. 61, 17-32.

Okubo, A., Yamazak, S., Fuwa, K., 1975. Biosynthesis of cercosporin. Agric. Biol. Chem. 39, 1173-1175.

Pall, M.L., Brunelli, J.P., 1993. A series of six compact fungal transformation vectors containing polylinkers with multiple unique restriction sites. Fungal Genet. Newslett. 40, 59-62.

Proctor, R.H., Brown, D.W., Plattner, R.D., Desjardins, A.E., 2003. Coexpression of 15 contiguous genes delineates a fumonisin biosynthetic gene cluster in Gibberella moniliformis. Fungal Genet. Biol. 38, 237249.

Ruzin, S.E., 1999. Plant Microtechnique and Microscopy. Oxford University Press, Oxford.

Sambrook, J., Russell, D.W., 2001. Molecular Cloning: A Laboratory Manual, third ed. Cold Spring Harbor Laboratory Press, Cold Spring Harbor, NewYork.

Seo, J.A., Proctor, R.H., Plattner, R.D., 2001. Characterization of four clustered and coregulated genes associated with fumonisin biosynthesis in Fusarium verticillioides. Fungal Genet. Biol. 34, 155-165.
Shim, W.B., Dunkle, L.D., 2003. CZK3, a MAP kinase kinase kinase homolog in Cercospora zeae-maydis, regulates cercosporin biosynthesis, fungal development, and pathogenesis. Mol. Plant-Microbe Interact. 16, 760-768.

Sims, J.W., Fillmore, J.P., Warner, D.D., Schmidt, E.W., 2005. Equisetin biosynthesis in Fusarium heterosporum. Chem. Comm. 2, 186-188.

Sollod, C.C., Jenns, A.J., Daub, M.E., 1992. Cell surface redox potential as a mechanism of defense against photosensitizers in fungi. Appl. Environ. Microbiol. 58, 444-449.

Spiering, M.J., Moon, C.D., Wilkinson, H.H., Schardl, C.L., 2005. Gene cluster for insecticidal loline alkaloids in the grass-endophytic fungus Neotyphodium uncinatum. Genetics 169, 1403-1414.

Spikes, J.D., 1989. Photosensitization. In: Smith, K.C. (Ed.), The Science of Photobiology, second ed. Plenum Press, New York.

Straubinger, B., Straubinger, E., Wirsel, S., Turgeon, G., Yoder, O.C., 1992. Versatile fungal transformation vectors carrying the selectable bar gene of Streptomyces hygroscopicus. Fungal Genet. Newslett. 39, 82-83.

Tanaka, A., Tsuge, T., 2000. Structural and functional complexity of the genomic region controlling AK-toxin biosynthesis and pathogenicity in the Japanese pear pathtype of Alternaria alternate. Mol. PlantMicrobe Interact. 13, 975-986.

Tudzynski, B., Hölter, K., 1998. Gibberellin biosynthetic pathway in Gibberella fujikuroi: Evidence for A Gene Cluster. Fungal Genet. Biol. 25, 157-170.

Walton, J.D., 2000. Horizontal gene transfer and the evolution of secondary metabolite gene clusters in fungi: An Hypothesis. Fungal Genet. Biol. 30, 167-171.

Yamazaki, S., Okube, A., Akiyama, Y., Fuwa, K., 1975. Cercosporin, a novel photodynamic pigment isolated from Cercospora kikuchii. Agric. Biol. Chem. 39, 287-288.

Yu, J., Bhatnagar, D., Cleveland, T.E., 2004. Completed sequence of aflatoxin pathway gene cluster in Aspergillus parasiticus. FEBS Lett. $564,126-130$. 


\section{Supplementary Figure (FGB-06-114R2) (A) O-methyltransferases (a. a. 1-429)}

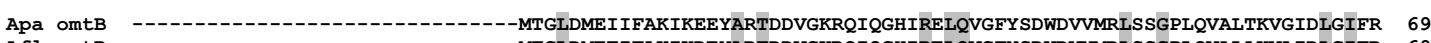
Afl omtB --CnA CTB3 MMQFQRDLEASLEAVSANAQELLKSLKSRKDVQDLNASLPKDPLDNCDAQTQAARAQLAEAATRILQLSIR-PQEYLEHLQNGYQHLTCFRWLVLNILD 99

Apa omtB SLKESDTPITLAEIVKKTGASPRLLGRILRTQAAFGLIKETGPQEYTSSAFTDVFAN-SDAAGAVVQLFDISGPCTQILPDFLAERNYQDITSNKDCVFQ 168 CnA CTB3 HLPHSGT-ISYTDLARKASVPPMQLRSICRMAICNGFLEEPEANQVRHSRISALFARDESYLGWARWMVNYSVPAAYKLSD--ATRSWGETVAKDQTAFN 196

APa OmtB KAFGSDLTMFEWMPQHPKHMESLGHLMALERPVSWVDHYPVLEELGGFPAPDKVLMVDIGGGFGQQSKALRAKFPDLPGRLIVQDIPQTLANAQPAAG-- 266 Afl omtB KAFGSDLTMFEWMPQHPKHMESLGHLMALERPVSWVDHFPILEELGKFPAPDKVLMVDIGGGFGQQSKALRAKFPNLPGRLIVQDIPQTLANAQPAAG-- 266 CnA CTB3 LGMDVKVPFFDLRQTPAMKDAFAAYMRNVTSNATWGLQHAVTGFDWASLPRGAKVVDVGGSLGHGSIAIAKEHTHLT--FVIQDLPETVAGARKEMAQN 294

APa omtB ---------IEFMEHNFFEPQPIQNAKFYYLRHVFHDWPDEQCVLILKQIIPAMGPESQILIDEMVIPSTG-----VPWQAAFTDLLMMNSLGGVERTR 351 Af1 omtB --------IEFMEHNFFEPQPIQNAKFYYLRHVFHDWPDEQCVLILKQIIPAMGPESQILIDEMVIPSTG-----VPWQAAFTDLLMMNSLGGVERTR 351 CnA CTB3 DKIEASVKSRITFQEHDFFGPQTVKDADVYFLRMICHDWPDNEAKVILSQIRAALKPGAQIVIMDTILPQPGTISVLQEQQLRIRDLTMMEVFNAKEREL 394

APa OMtB AEWDDLMEQVGLEIIQSKVYDSKEQAILVAVPKRT 386

Apa omtB AEWDDLMEQVGLEIIQSKVYSKEALIVAVPRT 386

$\begin{array}{llll}\text { Af1 } & \text { OMtB } & \text { AEWDDLMEQAGLEIIQSKVYDSKEQAILVAVAKRT } & 386 \\ \text { CNA } & \text { CTB3 } & \text { EDWSSLMQSAGLEISRVNQPLNSVMGLLTVRSAGQ } & 429\end{array}$

\section{(B) AFLS (a. a. 1-438)}

Af1 AFLS --MTLTDLETCAEEIATAARTLVRDGHTGGNS---------AGLPDHLRPVQRTLIANASQVLALASQPADLVRQLALYNQLLACLRWLGEFQVLAC 86 Afu AFLS -MDSITQLEARANEVAAAARRLAEYCRNARVDGAC---LPAVVPSEAPRAIREIQRLLLSNVDHLQILLTEPADLVQRLAVQSQLLSCLQWLGEFQVLAC 96 CnA CTB3 MMQFQRDLEASLEAVSANAQELLKSLKSRKDVQDLNASLPKDPLDNCDAQTQAARAQLAEAATRILQLSIRPQEYLEHLQNGYQHLTCFRWLVELNILDH 100

Af1 AFLS IPLDEPVPFEDVADIAGVPECRLRRLVRPLFTIGFLCEPSPGHVAHSVLSKQFVTQPALLDAILFMSETLAPSASTMGTQTRRFG-ASEHAEDSAWNMVV 185 Afu AFLS LPLTDTVSIADLARLSGVPEAOLARIIRFTITIGFLOEPORGHVAHSPLSSLFVSRPSLRDAVMFLADSAAPTALQMASATGRFGDTVASETDTAYNIAF 196 CnA CTB3 LPHSGTISYTDLARKASVPPMQLRSICRMAICNGFLEEPEANQVRHSRISALFARDESYLGWARWMVNYSVPAAYKLSDATRSWG-ETVAKDQTAFNLGM 199

Af1 AFLS GSDSPFAACLQQRPKVKRQLAAYLSYVSSAVDAAVEDTLTRMDWQNLG-MATVVHVGAQSPSLVVALAPQFPSLRFLVQTEAKTESGGHQPCLDNHGISA 284 Afu AFLS DHRDPFYFACEQRPKLQRRWSAYLQHTGGDARDLTQQVLSRVDWFNLN-NACVVEVLGPQSQSVTMMLDQLHPMLHFIVQEARIPNGSTHAALHQD---- 291 CnA CTB3 DVKVPFFDHLRQTPAMKDAFAAYMRNVTSNATWGLQHAVTGFDWASLPRGAKVVDVGGSLGHGSIAIAKEHTHLTFVIQDLPETVAGARKEMAQND---- 295

Af1 AFLS LKLANIPLHLRARITWGTRLSTATQPVIDAAVYLISIPSPSPQSPAMEITTRVAQALKAHVEVLRNNSDARLILTLPMSSATR-SMDAAARAAVSLSDLS 383 Afu AFLS ---------VRSVQIRELGGPQRVRDAAIYILNLG----PLPHAILSTSVLTELRAHFSVLAANSCAMLILTAGLLLPKPGAVDARVETSVRLHDLS 375 CnA CTB3 ----KIEASVKSRITFQEHDFFGPQTVKDADVYFLRMI------CHDWPDNEAKVILSQIRAALKPG--AQIVIMDTILPQPGTISVLQEQQLRIRDLT 382

Af1 AFLS LLQLTNGGSLNMGEIRDLLRSRSD---GLVVMREVRSPTNAVIAFEIQYRVDNDDNRY---- 438 Afu AFLS LLOLANDRLMEEDELVEMVHGVKDSVGRLAVVNRLHLPCTTTVALGVRYOAFGHGDSSAKSL 437 CnA CTB3 MMEVFNAKERELEDWSSLMQSAGL-----EISRVNQPLNSVMGLLTVRSAGQTALSGTNTL 438

\section{(C) FAD-dependent monooxygenases (a. a. 419-871)}

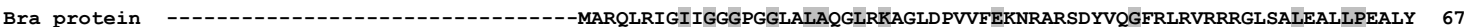
Rxy protein --10---10 Rxy protein ---
Chy protein - Chv protein - -
Phl protein CnA CTB3 MGLLTVRSAGQTALSGTNTLTPELVAAVSASTGSADSRPVIIAGAGIAGLCLAQALKKAGIDFRVFERDSHIDARPQGYRLKFEADAAQSLKNILPDDVY 518 ------

Bra protein QAVLDTAGRAPSETLQFDELLRPLDLRQGPD----PAADDALIEMSLSRITLRQVLLTGLDDIIAYGRTFASYTENADGS-VTAHFEDRSSEVFDVLVGA 162 Rxy protein DLSVATSIGSATRMVFLDHRLNEKFAKPIP-----PLAEDEFFGVN--RLTLREILLAGLEGVVHFGKTFERFEPVEDGR-VRAYFADGTTATGDLLVGA 170 Chv protein ELFRASCAVSG-PARFVDPQLNPLPGRRPENWRENADAGEAGGDLSADRQVLRDILSHGLAPQIRWGRRARGFERGGDG--IVVHCADGSEHGAALVVAA 161 Phl protein LAFEEASRYIGGOSRFYNERMRLLAVHGGIS--PMAGKIISEQRLSISRTELKEILNKGLANTIOWNKTFVRYEHIENGG-IKIFFADGSHENVDVLVGA 160

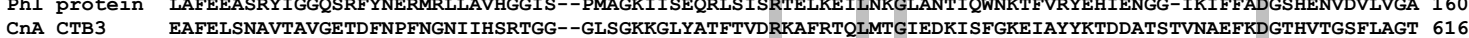

Bra protein DGAGSRVRAQLLPSARLIDTGARRFAGKVTFAEAERASLARVLQDYNVNI---RPTAGRTLMVTSHRVDPATFAAHGLIG-ANDPSHAGLAGRHFDNTAS 258 Rxy protein DGTDSRVRALLVPDAGLDELGAFIYGKTPITPGALEWVPDALVDSFNRMT---GPDGVSVSVATCIKRQPLACATARFAP-DLFLTEVQDYLAWMLNAPS 266 Chv protein DGLHSPLRRQWLPQAEPEAIGALNLYGKTPLDGIDPALLAGPTIVF--------ADGWTLVVEPMRFRAAMSGLAARHAP-DCRLSPTDDYVYWAMFGRE 252 Phl protein DGSNSKVRKQYLPFIERFDVGVSMI IGRARLTPALTALLPQNFRDG--------TPNSIVPKSPDWLFISMWRAPVNIHVEASLAEIDNFIVWVYVAAT 251 CnA CTB3 DGLHSVVRKTCVPNHRIVDTGAACIYGKTVMTPEFLARFPEKGLRFMTVVSDIAPMLQSCLIGDSPVTLLLEPIRFSEASRARYPELPPDYVYWALIGPK 716

Bra protein YVWWNVAFWRDEIAADATLEALDGRGLLELLLRHNANWHPELLKLIEITDPSTVAALKVRSSVP-VPPWPTRR-VTLLGDAIHSMTYFRALGANSAIHDA 356 Rxy protein ALLP---------LAREESRRADGPALHRLALGMLEGWHPSVRRIVEEADAASTFLVRLRSARP-VERWQASN-VTLLGDAIHTMSPGRGEGANTALRDA 355 Chv protein ACLG---------GSLSGEEDAAGWRRIEAASGGLHPGLSDLLRRTAPEAVMGRAVRMAAG-VPSWPPGR-LTVLGDAIHAMSPAGGVGANTALADA 339 Chv protein ACLG---------DNITDFSAEALCDLVOSRMISWDPSLHTLVOOSDMENISPLHLRSMPH-LLPWKSST-VTLLGDAIHNMTPMTGSGANTALRDA 337 CnA CTB3 ERFGSQE---VTSMKNFVSLDQAAEQAAKLSLAVTEEWHPSLRALFELQDTKQASLIRVASTIPDIPSWESHSNVTVLGGSIHPMSPCGGVGANTAIVDA 813

Bra protein GLLVPALVQIAAG-APLIETLAAYEAAMTAHGFAAVTDS-LAAMQRALGPNSIAA---------------- 409 Rxy protein ALIRRALVDAVTDRVPLYRAKARYETEMLRYGFRAVADSRNNPFAPRSGPGGSPV-- Chv protein AMLAVCLADGDVD---R--AVARYEADMRGRAERALVATRAGTERLLRRL------------ 384 Phl protein LLITQKLASVASGHEELVKAISDYEQQMRAYANEIVGISLRSAQNAVIHFSIPPLKQRHLSIRRNKSQSHQHRR 411 CnA CTB3 DALAKVLVEHGTK--PPVNAIAEFGAAMRTRAKRNIWRSEVGSKRMFGQKNLVDCSEFVF------------ 871 
Supplementary Fig. (FGB-06-114R2) (A) Alignments of the N-terminal CTB3 of Cercospora nicotianae (CnA) with S-adenosyl-methionine (SAM)-dependent $O$ methyltransferases (omtB) of A. parasiticus (Apa; GenBank accession nos. and A. flavus (Afl; GenBank accession nos. $\underline{\mathbf{A F 1 5 9 7 8 9}}$ ). A putative SAM-binding domain is indicated by dashed underlines. (B) Alignments of the N-terminal CTB3 of $C$. nicotianae (CnA) with the AFLS transcription co-regulator of A. fumigatus (Afu; GenBank accession nos. EAL89340) and A. flavus (Afl; GenBank accession nos. AAS90004). (C) Alignments of the C-terminal CTB3 of C. nicotianae (CnA) with flavin adenine dinucleotide (FAD)-dependent monooxygenases of Chromobacterium violaceum (Chv; GenBank accession nos. $\underline{\mathbf{A A Q 5 9 5 0 0}}$ ), Rubrobacter xylanophilus (Rxy; GenBank

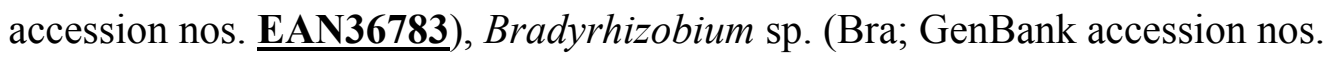
EAP27500), and Photorhabdus luminescens subsp. laumondii (Phl; GenBank accession nos. $\underline{\text { CAE14529)}}$. The putative FAD-binding domains are indicated by dashed underlines. 